\title{
Stimulation in Vitro of Galactocerebroside Galactosidase by N-Decanoyl 2-Amino-2-Methylpropanol
}

R.C. ARORA and N.S. RADIN, Mental Health Research

Institute, University of Michigan, Ann Arbor, Michigan 48104

\section{ABSTRACT}

Amides resembling ceramide (fatty acyl sphingosine) were synthesized and tested in vitro for their effects on the rat brain $\beta$-galactosidase which hydrolyzes galactosyl ceramide. The $\mathrm{N}$-decanoyl derivative of 2-amino-2-methyl-1-propanol was most effective, giving a $34 \%$ stimulation at $0.15 \mathrm{mM}$ concentration and a $60 \%$ stimulation at maximal levels. Addition of a hydroxyl group in the 3 position reduced the degree of stimulation, as did increasing or decreasing the length of the fatty acid portion. Omission of the branched methyl group resulted in inhibition instead of stimulation. Kinetic analysis indicates that the stimulator does not affect the binding of substrate to enzyme, but does speed the rate of hydrolytic action. Stimulation was also observed with the cerebrosidase in spleen and kidney. It is suggested that the stimulators act on an enzyme site other than the substrate-active site.

\section{INTRODUCTION}

Galactosyl ceramide $\beta$-galactosidase (cerebrosidase or galactocerebrosidase) is a specific enzyme which acts on one of the major lipids of brain $(2,3,6)$. It appears to require a bile acid for activity in vitro and the addition of fatty acid raises the activity additionally (4). Suzuki and Suzuki $(10,11)$ have shown that the enzyme is lacking in the hereditary disorder, Krabbe's disease, and have postulated that excessive acculumation of its substrate provokes the appearance in brain of globoid cells. These cells, in massive infiltration, apparently act to damage the brain fatally.

While the serum of one patient with Krabbe's disease was found to contain no detectable cerebrosidase, a small amount of activity was found inleukocytes, fibroblasts and brain (11). It is possible that the enzyme activity present in these patients, about $5-10 \%$ of normal, could be stimulated sufficiently by administration of a suitable drug, so that normal cerebroside metabolism could be maintained. Cerebrosidase activity normally rises considerably during myelination (4) and it is conceivable that normal development of a Krabbe child would ensue if it could be maintained during the critical stage of relatively rapid cerebroside turnover during early myelination $(7,9)$.

In the course of an attempt to synthesize compounds which could inhibit cerebroside hydrolysis (1), we found certain compounds which exerted a stimulatory effect. These compounds resemble ceramide, the product of cerebrosidase action, but differ in omission of the lipoidal side chain of sphingosine and

TABLE I

Stimulation of Cerebrosidase Produced by Fatty Acid Amides of Aminopropanols ${ }^{\mathrm{a}}$

\begin{tabular}{cccccc}
\hline & \multicolumn{2}{c}{$\begin{array}{c}\text { 2-Amino-2-methyl-1- } \\
\text { propanol }\end{array}$} & & \multicolumn{2}{c}{$\begin{array}{c}\text { 2-Amino-2-methyl-1,3- } \\
\text { propanediol }\end{array}$} \\
\cline { 2 - 5 } $\begin{array}{c}\text { Fatty acid } \\
\text { chain length }\end{array}$ & $\begin{array}{c}\text { Above } \\
\text { controls, } \%\end{array}$ & $\begin{array}{c}\text { Melting } \\
\text { point }\end{array}$ & & $\begin{array}{c}\text { Above } \\
\text { controls, } \%\end{array}$ & $\begin{array}{c}\text { Melting } \\
\text { point }\end{array}$ \\
\hline 18 & 12,8 & $64-65$ & 14,11 & $73-74$ \\
16 & 16,14 & $72-73$ & 11,7 & $69-70$ \\
14 & 30,26 & $48-49$ & 18,13 & $61-62$ \\
12 & 28,29 & $36-37$ & 20,16 & $46-47$ \\
10 & 59,50 & Oil & 24,26 & Oil \\
8 & 12,9 & Oil & 24,20 & Oil \\
\hline
\end{tabular}

aStimulations shown are from two separate experiments, each run in duplicate. The assay medium contained enzyme derived from $3 \mathrm{mg}$ of rat brain, $0.1 \mathrm{M}$ citrate $\mathrm{pH} 4.5,0.1$ $\mathrm{mg}$ of labeled cerebroside, $1 \mathrm{mg}$ of Tween, $0.5 \mathrm{mg}$ of Myrj, $0.37 \mathrm{mg}$ of Tris oleate and $2 \mathrm{mg}$ of $\mathrm{Na}$ taurocholate in $1 \mathrm{ml}$. Incubations ran for $3 \mathrm{hr}$ at $37 \mathrm{C}$. Control activities (withou: amides) were about $8000 \mathrm{cpm}$, corresponding to about $23 \mathrm{nmoles}$. The substrate specific activity was about $250 \mathrm{cpm} / \mathrm{nm}$ mole and the amount of amide in the incubation tubes was 0.3 $\mu$ mole. 


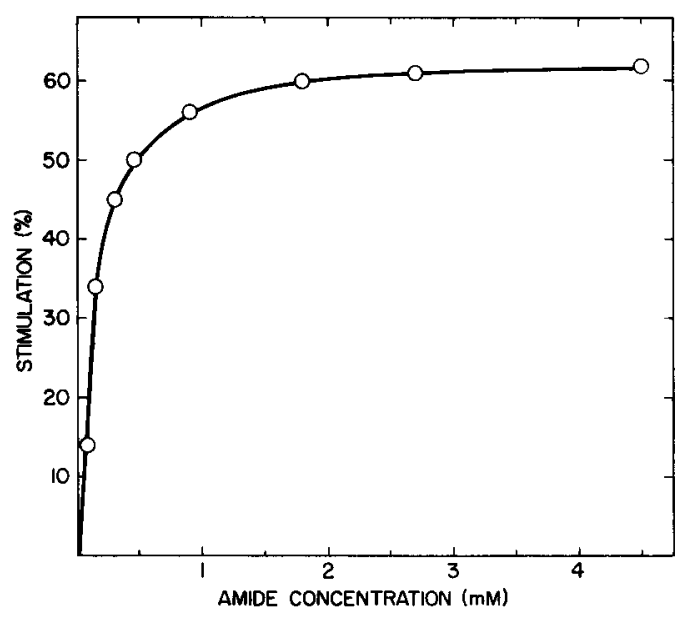

FIG. 1. The effect of increasing concentration of $\mathrm{N}$-decanoyl 2-amino-2-methylpropanol on rat brain cerebrosidase. Conditions as in Table I.

inclusion of a branched methyl group.

\section{METHODS AND MATERIALS}

The enzyme was prepared in crude form from the brains of 3-month-old rats as described before (4), and assayed by a simplified procedure (8). The assay medium contained galactose-labeled stearoyl psychosine emulsified with crude $\mathrm{Na}$ taurocholate, Tris oleate, Tween 20 and Myrj 59.

The synthetic compounds were made by acylation of amino alcohols with fatty acyl chlorides and characterized by thin layer chromatography, which showed a single spot (sometimes with a trace second spot) with each amide. IR spectra showed amide and alcohol peaks, but no ester peak. Details of the syntheses are described separately (1). The melting points of the compounds, which appear to be new, are given in Table I. Each compound was tested by evaporating a solution containing a weight sufficient to give a concentration in the medium of $0.3 \mathrm{mM}$. To this was added the substrate, diluent, citrate buffer and enzyme, in that order.

\section{RESULTS}

N-Fatty Acyl Amides of 1-Amino-2-Methyl-1-Propanol and 2-Amino-2-Methyl-1,3-Propanediol

The degree of stimulation for derivatives of fatty acids of different chain length is shown in Table I. The most effective compound was the decanoyl derivative of the methyl propanolamine. A sharp decrease in effectiveness resulted when a shorter or longer fatty acid was

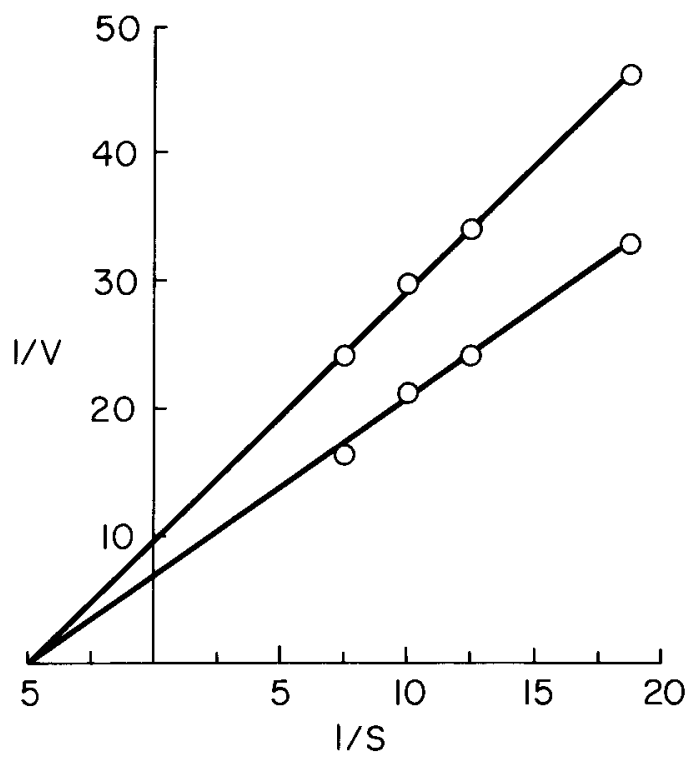

FIG. 2. The effect of changing the substrate concentration on the rate of hydrolysis. The concentrations of Tween, Myrj and oleate were changed too, in proportion to the cerebroside concentration. Upper line: control tubes; lower line: $0.3 \mathrm{mM}$ decanoyl aminomethylpropanol added. The unit of cerebroside concentration is $10^{-3} \mathrm{M}$ and the rate of reaction is in millimoles hydrolyzed in $3 \mathrm{hr}$. Incubation conditions were as in Table I.

used. At each chain length, except with stearate, the insertion of a second alcohol group reduced the stimulatory effect. When the branching methyl group was omitted (2-amino1-propanol), inhibition rather than stimulation was observed (1). The free amines and decanoic acid, which could conceivably arise by enzymatic hydrolysis of the amides, were slightly inhibitory.

A study with the two decanoate stimulators showed that preincubation of enzyme with buffer and amide, prior to addition of the substrate, did not materially affect the extent of stimulation. For the aminomethylpropanol derivative, the stimulation amounted to 60,51 and $54 \%$ with the preincubation periods of 60 , 30 and $0 \mathrm{~min}$, respectively. For the aminomethylpropanediol derivative, the corresponding stimulations were 25,27 and $22 \%$. The preincubation of the controls did not affect their activity.

To investigate the possibility that the stimulation was due to nonenzymatic catalysis of cerebroside hydrolysis, we incubated substrate with the decanoyl propanol derivative in the absence of enzyme. No increase above the blank value was observed. 
TABLE II

Stimulation of Cerebrosidase of Lyophilized Tissues by N-Decanoyl Amides

\begin{tabular}{lccc}
\hline \multicolumn{1}{c}{ Tissue } & $\begin{array}{c}\text { Control } \\
\text { activity, } \\
\text { cpm }\end{array}$ & $\begin{array}{c}\text { Aminomethylpropanol } \\
\text { Above control, \% }\end{array}$ & $\begin{array}{c}\text { Aminomethylpropanediol } \\
\text { Above control, \% }\end{array}$ \\
\hline Rat brain & 2020 & 20 & 9 \\
Rat spleen & 2677 & 16 & 11 \\
Rat kidney & 4099 & 29 & 23 \\
Rat liver & 831 & 7 & 2 \\
Rabbit gray matter & 377 & 5 & 3 \\
Rabbit white matter & 481 & 7 & 3 \\
\hline
\end{tabular}

${ }^{a}$ Tissues from rats were from 18-day-old animals; a brain from a 10-day-old rabbit was also used. In these assays the tissue was homogenized in a small volume of water and lyophilized. The powder was rehomogenized in benzene, aliquots containing $2 \mathrm{mg}$ of powder were dried down with a stream of nitrogen, and the incubation components were added as in Table I. The amides were added in solution and dried down prior to addition of the enzyme.

\section{Effect of Stimulator Concentration}

The data in Figure 1 show that decanoyl aminomethylpropanol produced a distinct stimulation at a concentration as low as $75 \mu \mathrm{M}$, and saturation of the effect appeared at about 1.8 $\mathrm{mM}$ and $60 \%$ stimulation. The saturation phenomenon is not due to limited solubility of the amide (which is somewhat lipoidal), since this would show up as a sharp discontinuity in Figure 1; the curve would suddenly flatten out at the solubility concentration. Moreover the amide must dissolve and combine rapidly with the enzyme, since a time study (15-180 min) showed that the control and stimulated reactions proceeded at constant rates.

\section{Kinetic Analysis of the Stimulation}

Evaluation of the stimulation effect at various concentrations of substrate yielded a Lineweaver-Burk plot (Fig. 2) which indicates that the $\mathrm{K}_{\mathrm{m}}$ of the enzyme-substrate complex was unchanged by the stimulator.

\section{Tests with Other Tissues and Compounds}

Although galactocerebroside is very rare outside the central nervous system, its hydrolase has been found in every tissue examined $(5,6,10,11)$. To test the possibility that extraneural cerebrosidase differs from the neural enzyme, we compared the effect of the two decanoyl amide stimulators on the enzyme activity in several tissues (Table II). Stimulation was seen in rat kidney and spleen, two major sources of the enzyme (6). The specific activity of the enzyme in liver was low, as noted before with freshly homogenized liver (6), and the activity in rabbit brain was even lower. However a more realistic comparison of rat and rabbit brain cerebrosidase activities must aw ait a detailed comparison at different ages, since marked changes occur with age.
It is not clear why the stimulatory effect of the amides with dried whole brain was so much less than with the purified enzyme.

The N-phenylacetyl amide of aminomethylpropanol (mp 129-130 C) yielded a stimulation of only $5 \%$ in the assay with purified cerebrosidase, and the corresponding diol (a semisolid) had even less effect ( $1 \%$ ). However the $\alpha$-bromo derivative of the former compound ( $\alpha$-bromophenylacetyl 2-amino-2-methyl-1-propanol, $\mathrm{mp}$ 73-74 C) produced $29 \%$ stimulation at $0.3 \mathrm{mM}$ concentration.

\section{DISCUSSION}

The ability of miscellaneous substances to increase the activity of an enzyme is an often-noted phenomenon. In this instance special interest comes from the rather sharp structural specificity involved, and the fact that the stimulator resembles the natural substrate structurally. Related compounds, which differ from the stimulators in possessing a lipoidal side chain and lacking the branched methyl group (thereby resembling natural ceramide more closely), act as noncompetitive inhibitors (1), and it may be that both groups of amides act by attachment to the same enzyme site.

It is likely that the stimulators act by combining in a reversible manner with the enzyme, producing a conformational change which increases the speed of enzyme action $\left(V_{\text {max }}\right)$. This idea is supported by the results of the Lineweaver-Burk plot (Fig. 2), which showed that the increase in enzyme activity is not owing to an effect on the strength of the enzyme-substrate binding $\left(\mathrm{K}_{\mathrm{m}}\right)$. If the stimulators act by an irreversible process, as by a chemical reaction with the enzyme, the reaction must be quite rapid, for we did not see any increased stimulation as the result of preincubation with stimulator, nor did the amount of 
stimulation increase with incubation duration. Moreover a chemical reaction of a simple amido alcohol with an enzyme seems unlikely.

Whether a stimulating substance can be made which will be therapeutically useful in Krabbe's disease remains to be seen. The $60 \%$ stimulation observed in our in vitro experiments could not be a sufficient effect, and we plan a search for more active compounds. From the results reported here, it would appear that a branching group at the 2 position is essential and that a substituent such as $\mathrm{Br}$ or $\mathrm{OH}$ in the acyl group is helpful. The latter is of particular interest as 2-hydroxy acyl groups occur primarily in galactocerebrosides, and the substituent might increase the specificity of the stimulator with respect to galactosyl ceramide (as opposed to glucosyl ceramide). A second hydroxyl group weakens the stimulator effect and an aromatic substituent at the 3 position produces inhibition (1). It remains to be seen, also, whether the same structural features are relevant to the cerebroside-hydrolyzing enzyme found in Krabbe's disease.

\section{ACKNOWLEDGMENTS}

This investigation was supported in part by Grant
NS-03192 from the National Institute of Neurological Diseases and Stroke, U.S. Public Health Service. I. Mason contributed technical assistance.

\section{REFERENCES}

1. Arora, R.C., and N.S. Radin, J. Lipid Res., in press.

2. Bowen, D.M., and N.S. Radin, Biochim. Biophys. Acta 152:599 (1968).

3. Bowen, D.M., and N.S. Radin, Ibid. 152:587 (1968).

4. Bowen, D.M., and N.S. Radin, J. Neurochem. 16:501 (1969).

5. Brady, R.O., A.E. Gal, J.N. Kanfer and R.M. Bradley, J. Biol. Chem. 240:3766 (1965).

6. Hajra, A.K., D.M. Bowen, Y. Kishimoto and N.S. Radin, J. Lipid Res. 7:379 (1966).

7. Kishimoto, Y., W.E. Davies and N.S. Radin, Ibid. $6: 525$ (1965).

8. Radin, N.S., and R.C. Arora, Ibid. $12: 256$ (1971).

9. Radin, N.S., F.B. Martin and J.R. Brown, J. Biol. Chem. 224:499 (1957).

10. Suzuki, K., and Y. Suzuki, Proc. Nat. Acad. Sci. $66: 302$ (1970).

11. Suzuki, Y., and K. Suzuki, Science 171:73 (1971).

[Received August 26, 1971] 